ORL/NUREG/TI-165

Dist. Category MRC-7

Contract No. W-7405-eng-26

Engineering Tcchnology DIvision

IAVEATORY AND REIATIVE BIOLOGICAL HAZARD OF LMFBR CORE MATERIALS

M. L. TobLas

Manuscript Coapleted - January 16, 1978

Date Pub11shed - January 1978

Prepared for the

U.S. Nuclear Regulatory Cornission

Office of thuclear Regulatory Research

Under Interagency Agreements DOE 40-551-75 and 40-552-75

NOTICE: This document contalns information of a preliminary nature. It 18 subject to revision or correction and therefore does not represent a final report.

Prepared by the OAK RIDGE MATIONAL LABORATORY Oak Ridge, Tennessee 37830 operated by UNION CARBIDE CORPORATION for the

\section{DEPARTMLAT OF ENERGY}

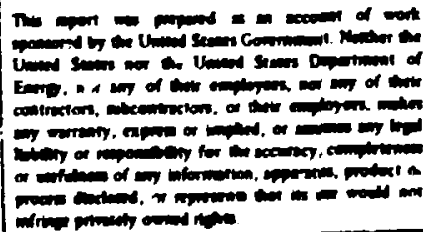

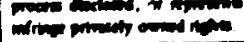




\section{coinsurs}

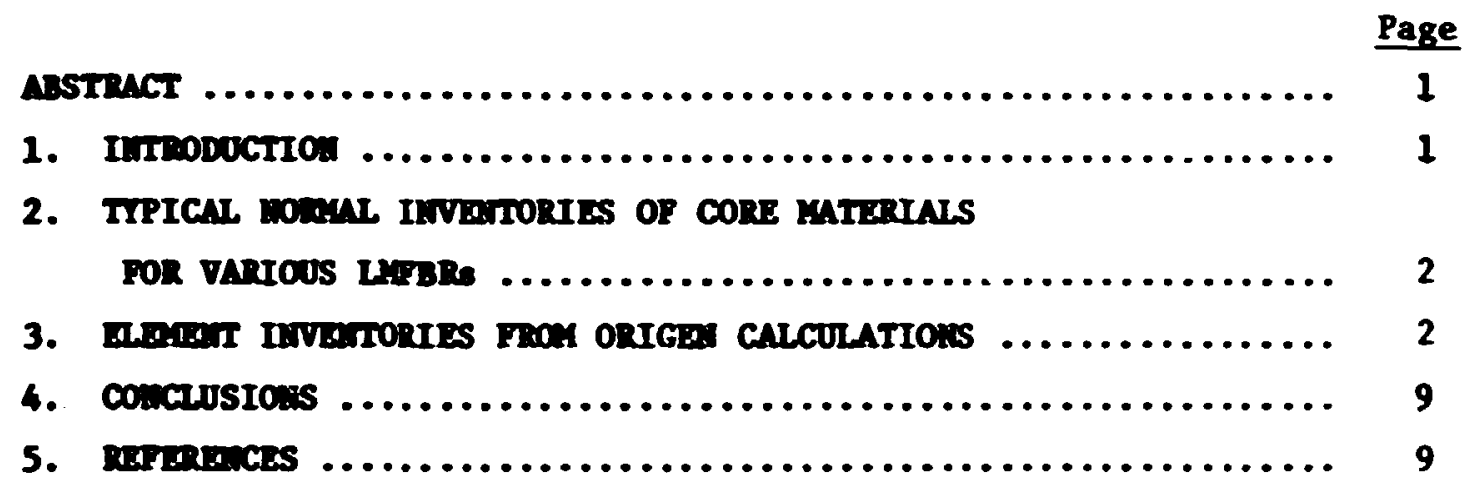


INVEITORY AND RELATIVE BIOLOGICAL HAZARD OF LMFBR CORE MATERIALS

M. L. Tobias

ABSTRACT

Information on the composition of an LPBBR core by element has been e.jllected on the basis of published design data and ORIGEN calculations. The mass quantities of structural materials, actinides, and fission products are in the ratio of $1: 1.4: 0.1$ with actinides, particularly plutoniu and neptunium, representing the najor inhalation and ingestion hazard. Sone of the fission products are present in quantities large enough to suggest that they warrant specific attention in source term analysis.

\section{INTRODUCTION}

This report discusses Information collected for the Aerosol Release and Trusport (ART) Program' at Oak RIdge National Laboratory. It is intended to be of use in estimating the potential composition of the material that may be released as a result of a hypothetical coredisruptive accident (HCDA) in a liquid-wetal-cooled fast breeder reactor (LMFBR).

Two types of information are presented. First, the nominal inventories of fuel, sodium, and structural materials for various LMFBR concepts are given. Next, results obtained from exssting ORIGEN ${ }^{2}$ rode calculations of 1sotope inventorfes for the case of a comercial-size LYFBR during full-power operation are 11sted. Gran quantities by element of fission products, actinides, and structural naterials are tabulated together with coments on relative biological hazards. Particular obfectives of the listings are (1) the identification of those constituents which have a high blological hazard, and yet make up only a small percentage by weight of a possible effluent, and (2) the identification of fission product elewents which are generated in mass quantities sufficient to have a possible effect on aerosol behavior. 


\section{TTPICAL MOMAL IMTENTORIES OF CORE MARERALS FOR VARIOUS IHFBRs}

Tuble 1, taken from various sources, ${ }^{3-6}$ gives the power, core volune fractions, and fissionable Inventory for experinental fast reactors, prototype reactors, and comercial-aise fast reactors.

Wre recent dealgas have been prepared as part of the Prototype Large Breeder panctor (PLBR) studies, ${ }^{7}$ detalls of uhich are not yet generally avalible. Advanced dealgo" imolving coacepts ouch as spolled gecetry and heterogeneous ("parfalt") coree would appear to require plutonio tonrictmente of about 16\%. Other dealga changes have been ade, but at this uriting it is not clear what bearing they ay have on serosol cource tern analyols.

The average and atandard deviations of ell the values of volume fractlons given in Table 1 are: fuel, $0.37 \pm 0.06$; eodiun, $0.37 \pm 0.09$; and other, $0.26 \pm 0.03$. Table 1 show that fuel inventory 18 a function of reactor power, wth reactors of the sane size having wore or less the ame anount of fuel. Plutonium/urariun ratios in the comercial reactors vary in the table from 0.14 to 0.25 . These figures indicate that it 18 not difficult to typify UFBRs from the standpoint of core voluse fractions, fuel inventory, or plutonlum fraction.

\section{ELDTETT IRVEITORIES FROM ORIGEN CALCULATIORS}

The assessment of the aerosol source term requires knowledge of the typee, gran quatitiea, and relative biological hazards of the anterials which ateht be releesed in an BCDA.

OAIGd code calculations for the stontcs International follow-on W.MBR are avallable wich are ueeful in such an evaluation. $2,5,9,10$ As wil be seen, the relative blologteal hazards. of the nuclides are not necesearily in the arme order as their gren quantities.

The baces of the calculation have been reconstructed as follows. befereace 11 states that the core Infentory 1819.09 metric tons (1 atric ton - $1000 \mathrm{~kg}$ ) of beary ental. The total power is $2400 \mathrm{MH}(\mathrm{t})$ and the core power frection is given as 0.917 . Ustug an 807 power 
Table 1. Fuel and volume fraction data for varlous fast reactor types

\begin{tabular}{|c|c|c|c|c|c|c|c|}
\hline \multirow{2}{*}{ Reactor } & \multirow{2}{*}{ Country } & \multirow{2}{*}{$\begin{array}{l}\text { Power } \\
\text { [MW(t)] }\end{array}$} & \multicolumn{3}{|c|}{ Core volume fraction } & \multicolumn{2}{|c|}{$\begin{array}{l}\text { Core loading } \\
\left(10^{\frac{3}{3}} \mathrm{~kg}\right)\end{array}$} \\
\hline & & & Fuel & Sodiu & Other & $\mathbf{w O}_{2}$ & $\mathrm{PuO}_{2}$ \\
\hline \multicolumn{8}{|c|}{ Experfmental fast reactor $s^{3}$} \\
\hline $\begin{array}{l}\text { Rapsodie F } \\
\text { PEC } \\
\text { Joro }\end{array}$ & $\begin{array}{l}\text { France } \\
\text { Italy } \\
\text { Japan }\end{array}$ & $\begin{array}{r}40 \\
118 \\
50\end{array}$ & $\begin{array}{l}0.42 \\
0.35 \\
0.36\end{array}$ & $\begin{array}{l}0.40 \\
0.37 \\
0.40\end{array}$ & $\begin{array}{l}0.18 \\
0.28 \\
0.24\end{array}$ & $\begin{array}{l}0.106 \\
0.76 \\
0.7\end{array}$ & $\begin{array}{l}0.045 \\
0.31 \\
0.15\end{array}$ \\
\hline $\begin{array}{l}\text { FFIT } \\
\text { EBR-II } \\
\text { Fermi } \\
\text { BOR-60 }\end{array}$ & $\begin{array}{l}\text { USA } \\
\text { USA } \\
\text { USA } \\
\text { USSR }\end{array}$ & $\begin{array}{c}400 \\
62.5 \\
200 \\
60\end{array}$ & $\begin{array}{l}0.35 \\
0.32 \\
0.27 \\
0.40\end{array}$ & $\begin{array}{l}0.41 \\
0.19 \\
0.46 \\
0.28\end{array}$ & $\begin{array}{l}0.24 \\
0.49 \\
0.27 \\
0.32\end{array}$ & $\begin{array}{l}2.13 \\
0.24 \\
1.88 \\
0.24\end{array}$ & $\begin{array}{l}0.723 \\
0.01\end{array}$ \\
\hline \multicolumn{8}{|c|}{ Prototype reactors ${ }^{3,6}$} \\
\hline $\begin{array}{l}\text { Phen1x } \\
\text { Phen1x } 450 \\
\text { SNR-300 } \\
\text { KWnju } \\
\text { PFR } \\
\text { CRBR } \\
\text { BN-350 } \\
\text { BN-600 }\end{array}$ & $\begin{array}{l}\text { France } \\
\text { France } \\
\text { Gernany } \\
\text { Japan } \\
\text { UR } \\
\text { USA } \\
\text { USSR } \\
\text { USSR }\end{array}$ & $\begin{array}{r}568 \\
1050 \\
762 \\
714 \\
612 \\
975 \\
1100 \\
1470\end{array}$ & $\begin{array}{l}0.36 \\
0.36 \\
0.31 \\
0.34 \\
0.36 \\
0.33 \\
0.46 \\
0.45\end{array}$ & $\begin{array}{l}0.36 \\
0.36 \\
0.50 \\
0.40 \\
0.42 \\
0.42 \\
0.32 \\
0.33\end{array}$ & $\begin{array}{l}0.28 \\
0.28 \\
0.19 \\
0.26 \\
0.22 \\
0.25^{a} \\
0.22 \\
0.22\end{array}$ & $\begin{array}{l}3.8 \\
8.0 \\
4.2 \\
4.4 \\
3.1 \\
5.3 \\
7.3 \\
6.5\end{array}$ & $\begin{array}{l}0.8 \\
1.8 \\
1.65 \\
1.5 \\
0.9 \\
1.85\end{array}$ \\
\hline \multicolumn{8}{|c|}{ Comercial reactors [power in $M H(e)]^{3-5}$} \\
\hline $\begin{array}{l}\text { Superphenix } \\
\text { CFR } \\
\text { B\&yb } \\
\text { CE }{ }^{b} \\
\text { AI }^{b} \\
\text { CE } b \\
\text { Westinghouse }\end{array}$ & $\begin{array}{l}\text { Prance } \\
\text { UR } \\
\text { USA } \\
\text { USA } \\
\text { USA } \\
\text { USA } \\
\text { USA }\end{array}$ & $\begin{array}{l}1200 \\
1250 \\
1000 \\
1000 \\
1000 \\
1000 \\
1000\end{array}$ & $\begin{array}{l}0.44 \\
0.39 \\
0.33 \\
0.47 \\
0.29\end{array}$ & $\begin{array}{l}0.17 \\
0.40 d \\
0.44 \\
0.38 \\
0.52\end{array}$ & $\begin{array}{l}0.39 \\
0.21^{d} \\
0.24 \\
0.15 \\
0.19\end{array}$ & $\begin{array}{l}30.6 \\
16 \\
c \\
e \\
16.6 f \\
15.1 g\end{array}$ & $\begin{array}{l}6.3 \\
4 \\
3.8 \\
c \\
2.5 f \\
2.19\end{array}$ \\
\hline
\end{tabular}

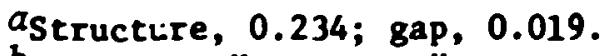

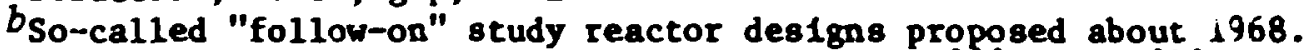
cAverage fissile enrichment of feed, 11.6 wt $\chi^{239} \mathrm{Pu}$ and ${ }^{241} \mathrm{Pr}$. d $0.0461 \mathrm{BeO}, 0.0155$ shim polson, 0.0213 safety polson. Sodium occuples shim position site unless tantalum rods are inserted.

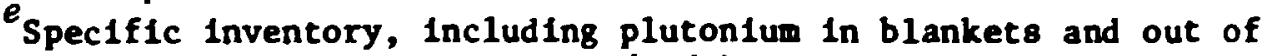
reactors, $3.6 \mathrm{~kg}$ of f1ssile material/ $\mathrm{kw}(\mathrm{e})$; seed region enrichment 10 to $122^{239} \mathrm{Pu}$ and ${ }^{261} \mathrm{Pu}$. fetimate from data in kef. 5.

getimate from data in Ref. 5. 
factor, we find

Core powerimetric in hery netal

$$
=(2400)(0.917)(0.8) ! 19.09=92.23 \text {. }
$$

(The actual ipput nuber was 92.17 M.)

Wo acterpt was ade to mock up the three-year cycle postulated in the follow-oa study; not only is it ankard to do so in the version of OAIGEs ued, but the elplification of using an average burnup time of tav years is also quite justifiable. (At the end of an equilibriun cjcle, onc-third of the core wll have been irradiated for one year, ow-third for two yenrs, and one-third for three years, resulting in an average exposure of two years.) The burnup per metric ton of heavy netal is therefore

$$
\text { (92.17 vidmetric ton) (2 years)(365 days/year) }
$$

$=6 ?, 284 \mathrm{Mdd} /$ netric ton.

The actual input nuber usad was 67,099. * The principal characteristics of the Atonics International follow-on reactor are outlined in Table 2.

Tables 3 to 5 list the wost significant elesencs in three classes ${ }^{\dagger}$ from the standpointe of ass Inventory and relative inhalation and ingestion hazsd. (The nelting and bolling points of the elements have been Included as incidental information; obviously, in any cases the nuclide w111 be present as a conpound.) Asouning that all the elements are released in an accident, the asses and hazards are in the ratios lieted in Table 6.

These tables pernit the ordering of concerns with particular elewents from the standpoint of aerosol source generation. Thus, the actinides appear far wore agnificant than fission products, which in turn are wich more hazardous than the structural naterials. The most

\footnotetext{
*The calculation was performed in 1972, anking it impractical to deternine the rsasons for these ainor differences.

the ORIGU code deals wth reactor aterials in three classes: (1) structural eaterials (e.8., coolant and cladding meterials); (2) actinides; and (3) fisolon products.
} 
Table 2. "Task III" Atonics International final reference design reactor characteristics ${ }^{6}$

\begin{tabular}{|c|c|c|c|}
\hline $\begin{array}{l}\text { Thernal power. Wu(t) } \\
\text { Cross electrical power, w(t) } \\
\text { Refueling cycle tine, years }\end{array}$ & $\begin{array}{l}2,100 \\
1,040 \\
1\end{array}$ & & \\
\hline $\begin{array}{l}\text { Reactor power fractions } \\
\text { Core } \\
\text { Axlal blaaket } \\
\text { Radial blanket }\end{array}$ & $\begin{array}{l}0.917 \\
0.031 \\
0.052\end{array}$ & & \\
\hline $\begin{array}{l}\text { Volwe fractions } \\
\text { Core and axtal blanket } \\
\text { Inner radial blanket } \\
\text { Outer radial blanket }\end{array}$ & $\begin{array}{l}\frac{\text { Puel }}{0.439} \\
0.556 \\
0.584\end{array}$ & $\begin{array}{l}\text { Sodiun } \\
0.326 \\
0.281 \\
0.269\end{array}$ & $\begin{array}{l}\text { Metal } \\
0.235 \\
0.163 \\
0.147\end{array}$ \\
\hline $\begin{array}{l}\text { Core fissile enrichments, at. } z \\
\text { Incer zone } \\
\text { Outer zone }\end{array}$ & $\begin{array}{l}10.5 \\
13.1\end{array}$ & & \\
\hline $\begin{array}{l}\text { Fissife masses }\left(\mathrm{Pu}+{ }^{235} \mathrm{U}\right), \mathrm{kg} \\
\text { Core } \\
\text { Axtal blanket } \\
\text { Radial blanket }\end{array}$ & $\begin{array}{l}2,191 \\
176 \\
377\end{array}$ & & \\
\hline $\begin{array}{l}\text { Initial loading }(\mathrm{Pu}+\mathrm{U}), \mathrm{kg} \\
\text { Core } \\
\text { Arial blanket } \\
\text { Radial blanket }\end{array}$ & $\begin{array}{l}19,090 \\
13,132 \\
15,688\end{array}$ & & \\
\hline
\end{tabular}

hazardous nuclides among the actinides appear to be plutonium and neptunium followed by lodine anong the fission products. However, this ordering is only an initial guide, for it assumes that all the elements are released equally, an unlikely assumption. Further analysis will certainly produce changes in their relative importance. 
Tab10 3. Inventory of etructural ateriala and thelr postirradiation hasarda

Ban1s: $1000 \mathrm{~kg}$ (1 watric ton) of U + Pu as chareed

Power - $92.17 \mathrm{kN}$; burnup $=67,099 \mathrm{kdd}$

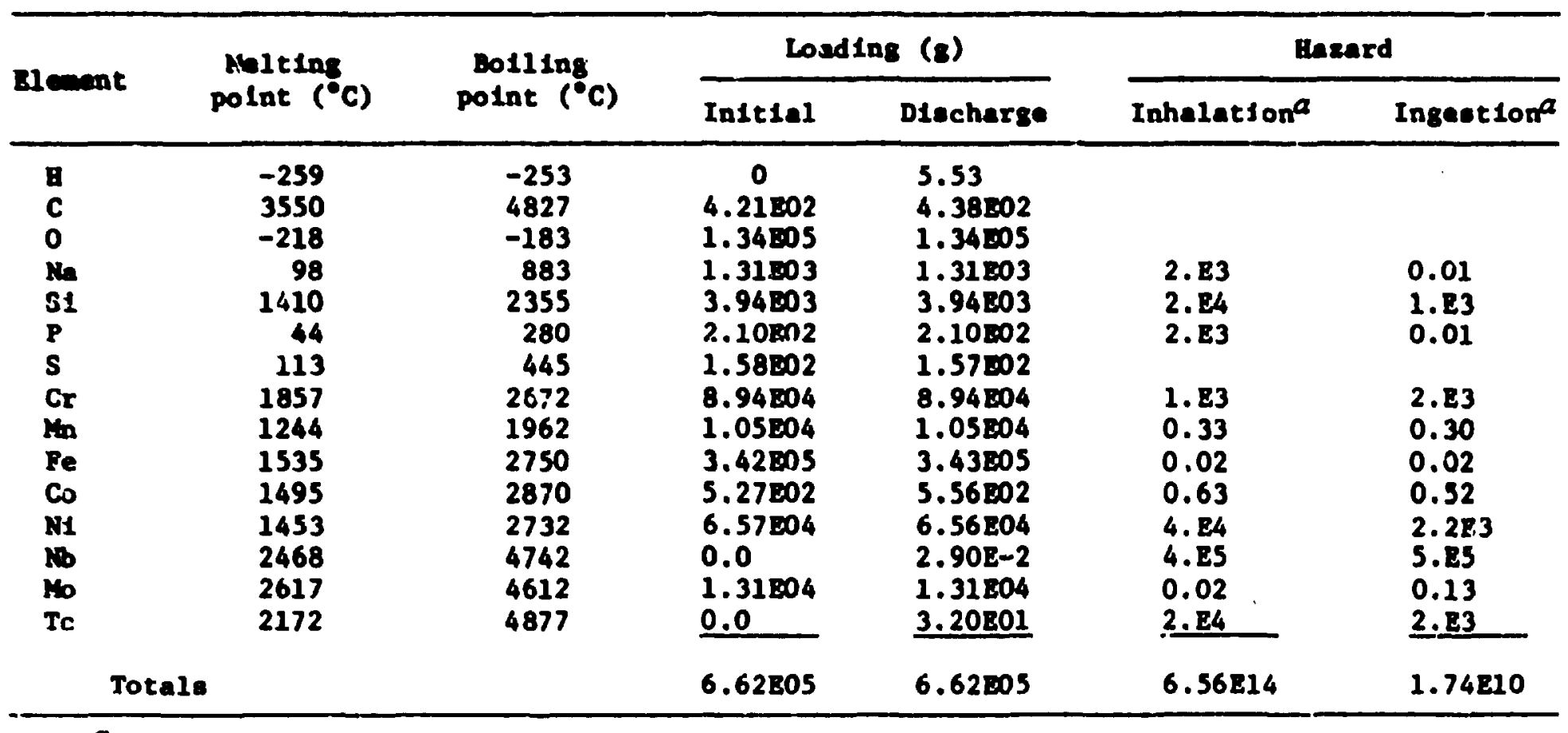

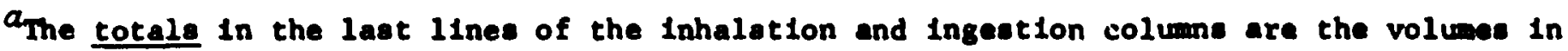
sublc neters of alr and water, respectively, required to dilute the radiosctivity in all the nuclides the code considers to levels given in Table II of Title 10 of the Cude of Federal Regulations, Part 20. The 11 gures for Individual elemente are fractiune of thie quantity and (rounded off) aum to 1.0 . 
Table 4. Inventory of accinides and their postirradiation hazards

Bas1s: see Table 3

\begin{tabular}{|c|c|c|c|c|c|c|}
\hline \multirow{2}{*}{ Element } & \multirow{2}{*}{$\begin{array}{l}\text { Melting } \\
\text { polnt }\left({ }^{\circ} \mathrm{c}\right)\end{array}$} & \multirow{2}{*}{$\begin{array}{l}\text { Bolling } \\
\text { poine ( }\end{array}$} & \multicolumn{2}{|c|}{ Loadine, (8) } & \multicolumn{2}{|c|}{ Hazard } \\
\hline & & & Intelal & Discharge & Inhalation ${ }^{a}$ & Ingestion ${ }^{a}$ \\
\hline $\mathbf{U}$ & $2865^{b}$ & $3487^{b}$ & $8.26 \mathrm{E} 05$ & $7.60 \mathrm{EOS}$ & $2.1 \mathrm{E}-7$ & $9.6 \mathrm{E}-5$ \\
\hline $\mathrm{Np}$ & 640 & 3902 & 0.0 & $4.56 \mathrm{EO} 2$ & $2.5 E-3$ & 0.953 \\
\hline Pu & $2390^{\circ}$ & $\sim 3200^{d}$ & $1.74 \mathrm{E} 05$ & $1.66 \mathrm{BO} 05$ & 0.94 & 0.029 \\
\hline Am & 994 & 2607 & 0.0 & $1.70 \mathrm{EO} 3$ & 0.02 & 0.006 \\
\hline C.m & 1340 & & 0.0 & $7.78 \mathrm{EO1}$ & 0.04 & 0.012 \\
\hline \multicolumn{2}{|c|}{ Totals } & & $1.00 \mathrm{E} 06$ & $9.28 \mathrm{E} 05$ & $1.24 \mathrm{E} 18$ & $6.40 \mathrm{E} 11$ \\
\hline
\end{tabular}

The totalg in the last lines of the inhalation and ingestion columns are the volumes in cublc meters of air and water, respectively, required to dilute the radivactivity in all the nuclides the code considers to levels given in Table II of Title 10 of the Code of Federal Regulations, Part 20. The flgures of individual elements are fractione of this quantity and (rounded of $f$ ) sum to 1.0 .

$b_{\mathrm{As}} \mathrm{UO}_{2}$.

${ }^{C} \mathrm{As} \mathrm{PuO}_{2}$.

$d_{A B}$ mixed oxide with $\mathrm{UO}_{2}$. 
Table 5. Inventory of fission products and their postirradiacion hazards

Basf: 1000 kg (1 wetric ton) of $\mathrm{O}+$ Pu es charged

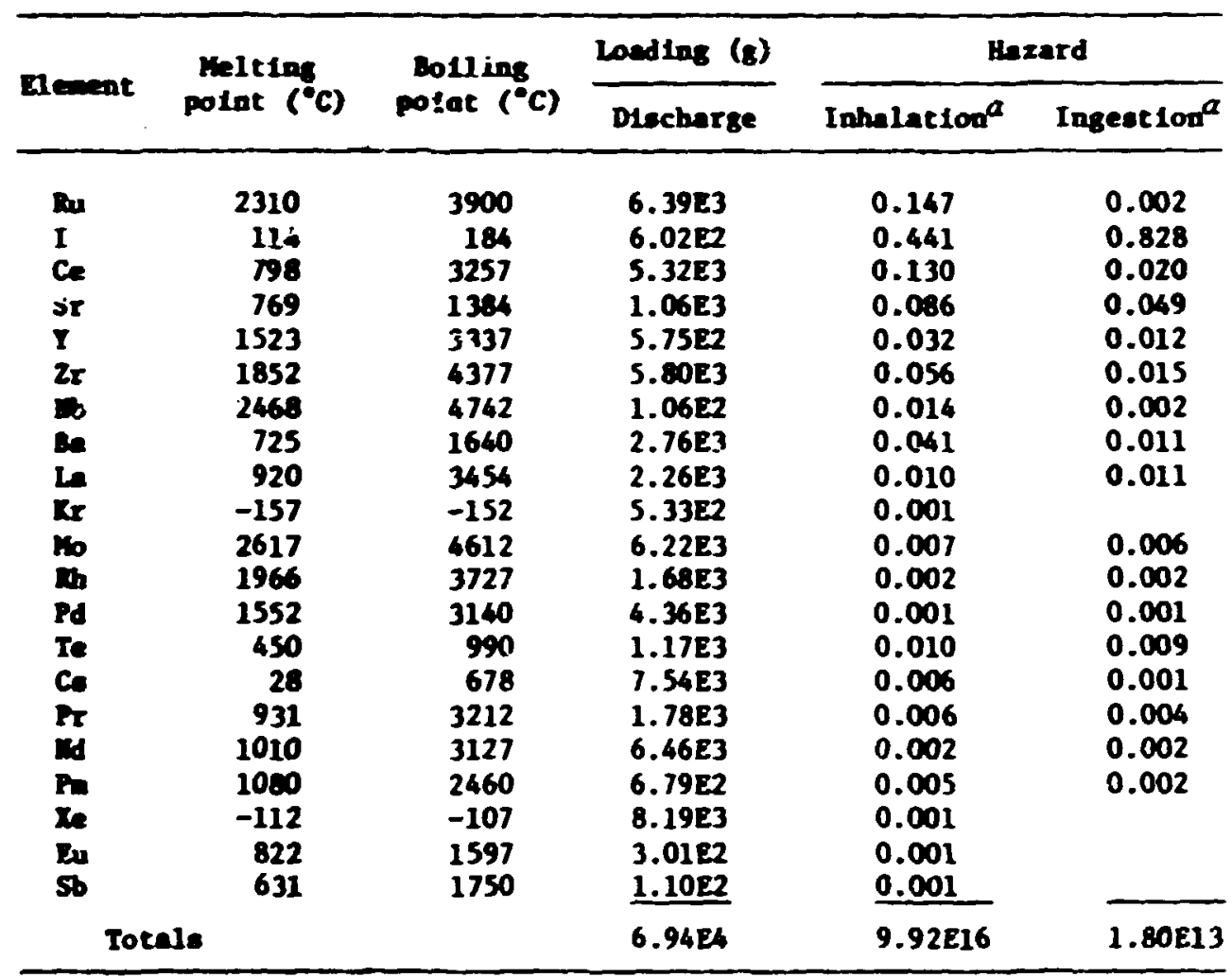

a The cocale is the last lines of the 1nhalation and ingeation colwe are the wolves in cublc meters of alr and vater, respectively, required to alluce the radiosctivity in all the nuclides the code considers to levele siven in Table II of Title 10 of the Code of Pederal Regulat10n. Part 20. The figures for Individual elements are fractions of thio quantity and (rounded off) an to 1.0 .

Table 6. Hase and hazard retios of the three clases of auclides in che Aconics Intermational follow-on renctor core $a$

\begin{tabular}{|c|c|c|c|}
\hline beclsde claoe & Mas & $\begin{array}{l}\text { Inhelecton } \\
\text { harard }\end{array}$ & $\begin{array}{l}\text { Ingestion } \\
\text { haserd }\end{array}$ \\
\hline Servecural & 1.0 & 1.0 & 1.0 \\
\hline Actinstas & 1.4 & 1890 & 1034 \\
\hline Plestod producte & 0.1 & 151 & 37 \\
\hline
\end{tabular}

a Inventories and hasards by feotope are also avallable but have bea onfted here for brevity. 


\section{CONCLUSIONS}

The gran quantities and constituents of material that aight be ejected fron the core of an WFBR following a core-disruptive accident have been assessed using published infornation on reactor designs and ORIGEN calculations. The ratio of mass quantities of structural materials, actinides, and fission products, is $1: 1.4: 0.1$. The inhalation and Ingestion hazards are malny from the actinides, led by plutoniun and neptunium. Gran quantities of fission products are not insignificant and should not be neglected in exanination of aerosol behavior.

\section{REFERENCES}

1. T. S. Kress et al., Sovice Term Assessment Concepts for LiFBRs: Aerosol Release and Transport (ART) Analy ical Progran, ORNL/NUREG/ TH-124 (1977).

2. M. J. Bell, ORIGEN - The ORNL Isotope Generation and Depletion Code, ORNL-4628.

3. International Working Group on Fast Reactors, MMPBR Plant Parameters, IWGFR-14 (December 1976).

4. Y. I. Chang, R. R. Rudolph, and C. E. Till, Alternative Fuel Cycle Options, RSS-Tr-4, Argonne National Laboratory (to be issued).

5. Proceedings of the International Conference on Sodium Technology and Large Fast Reactor Design, Nov. 7-9, 1968, Part II: Sessions on Large Fast Reactor Des1gn, ANL-7520.

6. 1000-Me LFFBR Follow-On Study, Task III Report, Conceptual Design Report, Sumary, AI-AEC-12792, (Vol. 1) (no date given but issued no later than February 1970).

7. Clinch River Breeder Reactor Project, Preliminary Safety Analysis Report, Chap. 4.

8. J. H. Roecker, "LMFER Commercial Plant Design," Trans. Am. Nucl. Soc. 26, 432 (1977).

9. J. C. Chandler et al., "Core Dest.gn Methods for Advanced LMFBRs," Trans. Am. Nuc1. Soc. 26, 447-48 (1977). 
10. A. R. Irvine, Chentcal Technology Division, Oak Ridge Natlonal Laboratory, personal comanication, 1977.

11. Staff of the Chenical Technology Division, Aqueous Processing of MirBR Fuels - Technical Assessent. and Experisental Progran Defin1t1on, OxIL-4436, 321 ff. (Jume 1970). 